\title{
Measuring Validity and Reliability of Perception of Online Collaborative Learning Questionnaire Using Rasch Model
}

\author{
Sharifah Nadiyah Razali",* , Faaizah Shahbodin" ${ }^{* \# \#, ~ M o h d ~ H a f i e z ~ A h m a d ~}{ }^{* *}$, Helmi Adly Mohd Noor ${ }^{\# \#}$ \\ ${ }^{\#}$ Kolej Komuniti Selandar, Jalan Batang Melaka, 77000 Selandar, Melaka, Malaysia \\ E-mail:shnadiyah@yahoo.com
}

*Faculty of Information and Communication Technology Universiti Teknikal Malaysia Melaka, Hang Tuah Jaya, 76100 Durian Tunggal, Melaka, Malaysia

E-mail:faaizah@utem.edu.my

\# Centre of Technopreneurship Development (C-TED) Universiti Teknikal Malaysia Melaka, Hang Tuah Jaya, 76100 Durian Tunggal, Melaka, Malaysia

${ }^{* * *}$ Kolej Komuniti Bukit Beruang, 23, Jalan Bukit Beruang Indah 1, Taman Bukit Beruang, 75450 Melaka, Malaysia E-mail: hafiezamani@yahoo.com

\author{
\#\# Universiti Kuala Lumpur, Malaysian Institute of Industrial Technology, \\ Persiaran Sinaran Ilmu, 81750 Bandar Seri Alam, Johor Bahru, Malaysia \\ E-mail: helmiadly@unikl.edu.my
}

\begin{abstract}
This study aims to generate empirical evidence on the validity and reliability of Perception of Online Collaborative Learning Questionnaire (POCLQ) using Rasch model. The questionnaire was distributed to 32 (N=32) Diploma Hotel Catering students from Politeknik Ibrahim Sultan, Johor (PIS). Data obtained was analysed using WINSTEP version 3.68 software. The finding showed that POCLQ had high reliability with five categories of difficulties items. So, it can be concluded that POCLQ is reliable and strongly accepted. Meanwhile, analysis of items fit showed there were six items that are not in the specified range and based on standardised residual correlation measurement value; there were five items found to be overlapped that should be dropped. All the items that needed to be dropped based on the analysis of result had been refined and retained for the purpose of the study and based on expert's view. Therefore, all items remained after Rasch analysis. It is hoped that this study will give emphasis to other researchers about the importance of analysing items to ensure the quality of an instrument being developed.
\end{abstract}

Keywords — soft skills; online project based collaborative learning; instrument validity; instrument reliability; Rasch model

\section{INTRODUCTION}

Education is important in contributing towards the future formation of an individual in the national development agenda. Through education, the development of human capital in terms of knowledge, skills and attitudes can be formed. Albano and Othman [1], [2] emphasise that the employability asset consists of knowledge, skills, and attitudes. With globalization, there is a big wave of change in the skills demand by employers. Most employers today look for soft skills rather than academic achievement as the primary criteria for the election of employee [3].

According to Abdullah [4] soft skills is crucial for the enhancement of employment performance and career prospects. Higher Education Institutions (HEIs) are confronted with the challenge of producing graduates who meet the needed skills of employers. Therefore, the development of soft skills in a study plan is extremely needed. $21^{\text {st }}$-century graduates are required to be equipped with skills that include critical thinking, problem solving, collaboration, and communication.

Interest in collaboration is a natural outgrowing trend in education towards active learning, whereby students become involved in constructing their own knowledge through discovery, discussion, and expert guidance. Collaborative learning is a learning approach that leads to the theory of constructivism [5] and it has been used as a learning strategy that has been practiced worldwide for many years [6]. Many 
published reports have outlined the advantages of collaborative learning suggesting that it improves academic performance, promotes soft skills development (i.e., communications, collaboration, problem-solving, and critical thinking skills), and increases satisfaction in the learning experience [7]-[10].

The benefits of collaboration in learning have been proven by Social Constructivism [5], [11], [12]. However, collaboration does not often happen naturally in a group. To establish and maintain active collaboration is a challenging task due to the lack of or low participation of other group members to participate actively in the group work [13]. Some members do not participate or do not contribute to group work [14]. Young [15] report on studies based on western students that stress on the role of collaboration in enhancing student learning achievements. However, Zhu [7] affirms that only a few empirical studies have examined student satisfaction, performance, and knowledge construction through collaboration from a cross-cultural perspective. Researches eg. by Santhanam et. al; So and Brush; and $\mathrm{Wu}$ et. al [16]-[18] critically question on student's satisfaction in collaborative learning environments.

Frustration is a common feeling among students involved in collaborative learning experiences because educators assume that every student makes an equal contribution [19] and same grades are awarded to each team member [20]-[22] even despite the imbalance in the level of commitment by students [23]. Hence, there is a need to monitor and evaluate students' contribution in group work which, on the other hand, encourage student participation [22], [24], [25]. But it is difficult for educators to monitor and evaluate the learning process [21], [26] as collaborative learning activities were mostly done outside of class time. Students also reported that it was difficult to meet outside class [21] so that educator is not able to ensure the presence of each team member at each meeting. Therefore, instructors are not able to observe all the processes occurring within the student groups and evaluation is done based on the quality of the final product, ignoring the teamwork process [8]. Certain strategies must be applied to monitor and evaluate the learning process. Technology can be used to measure soft skills [27] and monitor collaborative learning process [28], [29]. Assessment through online platform provides an advantage as students' conversations are recorded in writing [30].

Arend; and Gaytan and McEwen [31], [32] suggest the use of online discussions to grade students' activity. Learning Management System (LMS) provides online discussion features such as discussion boards and forums to facilitate communication and collaborative work in online learning environments. But Gleadow et. al [33] elucidate that current LMS discussions and forums do not support engagement and accessibility. Stromman [34] emphasise that if the online platform is unable to facilitate collaborative learning it will cause low active participation. Therefore, the communication features of LMSs are poorly utilised in most institutions Affendi et. al [35] and the lecturer prefers to employ the Social Networking Sites to facilitate their communication.

Even though Collaborative Learning (CL) has been proven to promote soft skills [8], [9], [36]-[39]. Previous literature [40], [41] and this study's preliminary findings show that CL has been widely implemented in teaching and learning. Then again, the question arises as to why students' mastery of soft skills is reported to be low. This indicates that although CL is implemented widely in the teaching and learning process, it does not often naturally happen in a group. It is difficult to monitor and at the same time to evaluate the CL process as CL activities are mostly conducted outside of class time. Swan et. al, Andresen and Brindley et. al [42]-[44] stated that the evaluation of students' contributions in group work encourages them to participate actively in group activities. This is also helpful in overcoming the free rider issue which is often mentioned by previous researchers [45], [46]. Here arises the importance of online platform for the facilitation of CL environments.

Nowadays most educational institutions adopt LMS via the used of open sources such as Moodle and Sakai or commercials such as Blackboard to centralise contents, learning and assessment activities in a specific learning environment [47], [48]. LMS provides a variety of communication tools such as a forum, chat, discussion board and video or audio conferencing [49], [50]. Learners can use these features to facilitate their communication and collaborative work in this learning environment [51]. LMS improves the quality of teaching and learning by enabling educators to monitor [52] and evaluate [53] the students' involvement. Moreover, LMS offers opportunities for increased collaboration through the interaction function [34]. Currently, Moodle (Modular Object Oriented Dynamic Learning Environment) is the most popular LMS because it is a free open source [54]-[57]. Moodle was developed by Dougiamas (1998) based on social constructivism pedagogical philosophy [58]. Therefore, it has been widely adopted by institutions. Furthermore, Polytechnics have designed and developed their own LMS using Moodle platform called CIDOS (Curriculum Information Document Online System). Therefore, OPBCL will be developed using Moodle platform.

Even the advantages of LMS are commonly known, and it is a well-known fact that without appropriate pedagogical support, the effectiveness of online learning cannot be produced. Concerns arise among educators about the use of learning theory in online learning [59]-[61]. The studies have been reported that most online learnings do not incorporate any learning theory or pedagogy. Witte et. al; Kivunja; and Al-Ansari et. al [53], [62], [63] emphasised the use of appropriate learning theory in online learning to increase learning effectiveness. Furthermore, previous studies have highlighted that LMS has not been fully utilised by educators. LMS provides many types of tools [49] such as communication, productivity, assessment and course management features [64]. However, educators have been found to use only the productivity feature such uploading and sharing notes or handouts while ignoring other features ([35]. Besides, the study also reported that HEIs are still using LMS in teaching due to the course content facilities. Therefore, the frequency in the use of LMS by the HEIs is very low and has become unpopular among educators ([65].

Besides that, the drawback of LMS is that uninteresting interfaces may result in decreased students' motivation [66]. Based on students' perspectives, educators must use an attractive layout that students familiar with in order to 
facilitate OCL [67]. In addition, Gleadow et.al [33] report that LMS face challenges in terms of engagement and accessibility. Previous literature has discussed on the communicational features of LMS which are poorly utilised in most institutions. This is because LMS do not provide supportive environments that can support interaction and communication [56], [66]. Due to the incapability and limitations of LMS, such as networking and communications [68], lecturers sought for other applications as a replacement for the built-in discussion forum in LMS [56], [69]. Martins et. al [70] also suggest on replacing traditional LMS with Social Networking Sites.

Social Networking Sites (SNSs) are an online services, platforms, or sites that focus on facilitating the building of social networks or social relations among people who, for example, share interests, activities, backgrounds, or real-life connections. SNSs are a part of Web 2.0 tools that have become the most of the crucial communication tools nowadays. There is no specific definition of Social Networking Sites [71]. However, it's the core features of are to facilitate interaction and collaboration among users. Since their introduction, SNSs such as Myspace, Facebook, and Twitter have attracted millions of users, many of whom have integrated these sites into their daily practices. SNSs provide users a platform to share information, exchange views, and support interaction [72]. Moreover, SNSs supported constructivist approach in learning in order to increase students' knowledge construction and to promote interaction [73]. Zaidieh [74] was described these networks as social because it allows communication and strengthens the ties between members on the Internet.

Various studies have been conducted to examine SNS's usages in education [66]. These studies showed that SNSs enable interaction, collaboration, resource sharing, active participation, and critical thinking in educational activities [75]-[79]. Wheeler et.al, Rifkin et.al and Zourou [80]-[82] suggested that SNSs could be used to enhance the relationship, improve motivation, offer personalized material and develop collaborative skills. According to Smith (2009), SNSs are capable of promoting the development of online community and extend learning beyond the classroom. Meanwhile, studies by Barbour and Plough; Zakaria; and Ventura and Martin-Monje [79], [84], [85] argued that the incorporation of social media into blended learning course can enhance the learning experiences. Moreover, Silius et. al [86] found that SNSs could improve collaborative learning and social interaction by attracting and motivating the student to participate in the learning process.

Even though earlier evidence have indicated the effectiveness of SNSs, some argue that SNSs distract learners where students spend less time in their studies thus resulting in lower knowledge performance [87]-[91]. Conversely, Pasek et. al [92] replicated study that investigated the relationship between Facebook use and which had grade reported opposite. A similar result was reported by Wang et.al [93] study which reported that SNSs do not academically improve the learning process. Although several studies have indicated that SNS enable interaction, collaboration, resource sharing, active participation, and critical thinking in educational activities [75]-[78], but it simply cannot be successful in meeting the students' needs.
It can only be used as a supplement in the teaching and learning process [68]. Earlier, previous researches have suggested on replacing LMS with SNSs due to its potential in enhancing communications, community building, and engagement, however, a study by Buzzetto-more [94] reported opposite where student do not want SNSs to replace LMS.

Many researchers in the field of education have looked into the potential of adapting SNSs in their teaching and learning process [65], [95], [96], various studies have focused on the integration of conventional LMS such as Moodle with SNSs. This has left a gap in the body of knowledge on how SNSs can be integrated into LMS platform to facilitate Online Collaborative Learning (OCL) which would promote the development of soft skills. Therefore, with the availability problem as stated, then the study to propose effective online learning environment that can facilitate Collaborative Learning is significant.

In continuation of the previous study [97]-[99], Online Project-Based Collaborative Learning (OPBCL) prototype was developed based on the model proposed to enhance students soft skills [100]. Therefore, research testing instrument must be developed to evaluate the effectiveness of OPBCL. Research testing instrument plays an important role in collecting data to answer the research questions that have been set [101]. A research testing instrument called Perception of Online Collaborative Learning Questionnaire (POCLQ) was developed to measure learners' perception towards OPBCL.

The main quality indicators for any testing instrument in research are the reliability and validity [102]. It is important to get the validity and reliability of an instrument before carrying out the actual study to ensure the smooth process of the actual study. Therefore, this study aims to determine the validity and reliability of POCLQ.

Validity is the extent to which a research testing instrument measures what it is supposed to measure. Therefore, good conclusions can be made from the sample of study [103]. Meanwhile, reliability is the extent to which a research testing instrument can be expected to obtain consistent results when repeated. The reliability can provide a consistent validity [104]. Furthermore, review and validation by a domain expert are required to ensure that the instrument meets its objectives [104], [105]. Therefore, expert validation was conducted before performing a pilot study.

Two types of validation which are face and content validation were performed by three experts in online collaborative learning (lecturer from Public Institution), three subject matter experts (lecturer from Malaysia Polytechnic) and three experts in the developer of system design. Face validation aims to check the language used and the presentation of the overall layout of instruments. For content validation, Aiken [106] stated that it intended to examine the extent to which the ability of a measuring instrument to measure what should be measured.

Then, a pilot study was conducted to test the reliability of the instrument used. Reliability is the extent to which a research testing instrument can be expected to obtain consistent results when repeated. Rasch model approach was implemented to check the reliability and validity of the 
instruments used. In recent years, Rasch models also referred as item-response theory (IRT) or latent trait models, have provided an alternative framework for understanding measurement and alternative strategies for judging the quality of a measuring instrument [102], [107]. Applications of Rasch model can produce an instrument that is reliable and valid [108]. According to Azman [109], there are eight diagnostic data analysis in the instruments development process such as (i) the reliability and separation item respondents, (ii) polarities item, (iii) the compatibility (fit) item, (iv) the value of standardized residual correlation in determining leaning item (v) the distribution of item difficulty levels and abilities respondents (vi) Differential The items Functioning (DIF) based on gender; (vii) the appropriateness of the measurement scale based on the use of categories; and (viii) unidimensional.

However, the use of this form of diagnosis depends on the needs of the study. In determining the validity and reliability of the POCLQ, the item functionality only checks perform on (i) the reliability and separation item respondents, (ii) polarities item, (iii) the compatibility (fit) item, (iv) the value of standardized residual correlation in determining leaning item and (v) the distribution of item difficulty levels and abilities respondents.

\section{MATERIALS AND METHODS}

\section{A. Design of study}

The study conducted in the form of a descriptive survey study. According to Cohen and Manion in Ghaffar [110], the survey is to take the data at a certain time, often using questionnaires. Therefore, researchers choose to distribute a set of questionnaire to each respondent to obtain feedback easily.

POCLQ was developed to measure learners' perception towards the proposed prototype. The development of the instrument is based on the steps used in Jamil [101] study which are: (i) identify constructs and elements based on document analysis, (ii) expert validation on the constructs and elements that have been previously identified, (iii) item development (iv) expert validation of the developed instrument and (v) pilot test run.

\section{B. Instrument}

The instrument was developed based on the OCL construct of (i) learning environment, (ii) learning design, (iii) learning interaction and (iv) soft skills. The development of items was adapted and modified from [111][115]. The items also have been agreed upon by experts based on literature through the theories related to construction and dimensional constructs. This instrument is divided into two sections:

1) Section A: Section A is related to the background of the respondents. This section contains nine items related to gender, age, residence, computer literacy, CIDOS experience, CIDOS forum experience, SNSs experience, Facebook account and PBL experience.

2) Section B: Section B consists of items that are designed to assess student's perception toward the proposed prototype. The section contains 37 items developed based on factors and elements that have been identified before in [97].
Table 1 shows the content of the questionnaire and the number of items included in this section.

TABLE I

Questionnaire CONTENT AND Number of ITEMS In SECTION B

\begin{tabular}{|c|c|c|c|}
\hline Factor & Element & No of Item & Total \\
\hline \multirow{4}{*}{$\begin{array}{l}\text { Learning } \\
\text { Environment }\end{array}$} & Usability & LE1-LE6 & 6 \\
\hline & Accessibility & LE7-LE9 & 3 \\
\hline & Stability & LE10-LE12 & 3 \\
\hline & Overall & LE13-LE14 & 2 \\
\hline \multirow{5}{*}{$\begin{array}{l}\text { Learning } \\
\text { Design }\end{array}$} & Content & LD1-LD3 & 3 \\
\hline & Time & LD4-LD5 & 1 \\
\hline & Process & LD6-LD8 & 3 \\
\hline & Evaluation & LD9-LD11 & 3 \\
\hline & Overall & LD12 & 1 \\
\hline \multirow{3}{*}{$\begin{array}{l}\text { Learning } \\
\text { Interaction }\end{array}$} & Learner-learner & LI1-LI3 & 3 \\
\hline & Learner-teacher & LI4-LI6 & 3 \\
\hline & Overall & LI7 & 1 \\
\hline \multirow{4}{*}{ Soft Skills } & $\begin{array}{l}\text { Critical Thinking and } \\
\text { Problem-Solving }\end{array}$ & SS1 & 1 \\
\hline & Collaboration & SS2 & 1 \\
\hline & Communication & SS3 & 1 \\
\hline & Overall & SS4 & 1 \\
\hline
\end{tabular}

The respondents answered the questionnaire using Likert scale. According to Likert in 1974, the rate or level of agreement on a question can be obtained using Likert scale. This study used a 6 Likert scale to avoid students from choosing a midpoint answer in 5 Likert scale. According to Chomeya [116], using a 6 Likert scale can reduce the deviation of personal decision making. Furthermore, a 6 Likert scale was chosen when the respondents were needed to answer either the positive or negative perception. A 5 Likert scale is not suitable for use in this study because the respondents had prior experience using the developed prototype. A 5 Likert scale is used only if there is concern that the respondents are not familiar with the environment being studied. The scale used was (1) strongly disagree, (2) disagree, (3) somewhat disagree, (4) somewhat agree, (5) agree and (6) strongly agree as illustrated in Table 2.

TABLE II

LEVEL OF AGREEMENT SCORE

\begin{tabular}{|l|l|l|l|l|l|l|}
\hline Score & $\mathbf{1}$ & $\mathbf{2}$ & $\mathbf{3}$ & $\mathbf{4}$ & $\mathbf{5}$ & $\mathbf{6}$ \\
\hline $\begin{array}{l}\text { Level of } \\
\text { Agreement }\end{array}$ & $\begin{array}{l}\text { Strongly } \\
\text { Disagree }\end{array}$ & Disagree & $\begin{array}{l}\text { Somewhat } \\
\text { Disagree }\end{array}$ & $\begin{array}{l}\text { Somewhat } \\
\text { Agree }\end{array}$ & Agree & $\begin{array}{l}\text { Strongly } \\
\text { Agree }\end{array}$ \\
\hline
\end{tabular}

\section{Respondents}

The pilot study respondent selection was based on purposive sampling. According to Denscombe (2010), purposive sampling is a way of getting the best information by selecting respondents who are most likely to have the experience to provide quality information and valuable insights on this research. For the purpose of the pilot test, Politeknik Ibrahim Sultan was selected for computer equipment and internet connection capabilities. In addition, the administration and lecturers also showed interest and cooperation during the preliminary study process. A total of 32 respondents were involved in the pilot study sessions, and it involved students who have taken the Nutrition subject. The subjects were selected based on discussions with the 
head of the program as the nature of Nutrition subject is a theory-based subject and also a curriculum that requires project assignment in the syllabus. Since Nutrition is a theory-based subject, students were passive in comparison to hands-on subjects. The implementation of the CL in theoretical subject increases students' learning effectiveness [118]. Data obtained was analysed using WINSTEP version 3.68 software.

\section{RESULTS AND DISCUSSION}

The development of Perception of Online Collaborative Learning Questionnaire (POCLQ) used in this study was developed using 6 Likert scales. The finding will be discussed according to reliability and separation index, items validity and variable map.

\section{A. Reliability and Separation Item}

Results from the analysis of POCLQ showed that the value of Cronbach Alpha $(\alpha)$ is 0.95 as shown in Table 4. According to Zikmund and Babin [119], the Cronbach Alpha value of the POCLQ instruments are very good and effective with a high level of consistency and can be used for the real study. Cronbach Alpha value was interpreted as in Table 3 below.

TABLE III

CRONBACH ALPHA INTERPRETATION SCORE

\begin{tabular}{|l|l|}
\hline $\begin{array}{l}\text { Cronbach Alpha } \\
\text { Score }\end{array}$ & $\begin{array}{l}\text { Value } \\
\text { Interpreted }\end{array}$ \\
\hline $0.8-1.0$ & High Reliability \\
\hline $0.7-0.8$ & Good Reliability \\
\hline $0.6-0.7$ & Fair Reliability \\
\hline$<0.6$ & Poor reliability \\
\hline
\end{tabular}

Besides that, person reliability value is 0.95 , indicating a high reliability with a 4.19 separation index (Table 4) that showed five categories of difficulties items. Bond and Fox [120] described the reliability of more than 0.8 as very good and strongly acceptable. Meanwhile, Linacre [121] stated that the separation of more than two is good value. The findings indicate that the item has high reliability and five categories of difficulties items are detected.

TABLE IV

RELIABILITY

\begin{tabular}{|l|l|l|}
\hline Cronbach Alpha $(\boldsymbol{\alpha})$ & Reliability & Separation \\
\hline 0.95 & 0.95 & 4.19 \\
\hline
\end{tabular}

\section{B. Items Validity}

Item validity was measured according to Point Measure Correlation (PTMea Corr.), INFIT and OUTFIT mean square (MNSQ) and Standardised Residual Correlation.

Table 5 showed the PTMea Corr. value of item polarity. Examination of the polarities item is intended to test the extent to which the developed construct achieves its goals and the relationship among the developed items of the respondents. Based on the analysis, the PTMea Corr. showed no negative value items, therefore no items should be dropped. According to Bond and Fox [26], to determine whether the item measured the constructs, the value shown on the PTMea Corr. must be in the positive (+). If the value obtained is negative (-), it means that the developed item does not measure the construct, and it should be dropped or refined because it is difficult or not leading to questions (out of focus). The findings also indicated that the items that are produced could measure any item to be measured, and it is moving in one direction with other items that measure the construct.

TABLE V

ITEM POLARITY

\begin{tabular}{|c|c|c|}
\hline Entry Number & PTMea Corr. & Item \\
\hline 22 & .48 & LD8 \\
\hline 4 & .49 & LE4 \\
\hline 12 & .49 & LE12 \\
\hline 34 & .52 & SS1 \\
\hline 5 & .53 & LE5 \\
\hline 35 & .54 & SS2 \\
\hline 18 & .55 & LD4 \\
\hline 17 & .56 & LD3 \\
\hline 37 & .57 & SS4 \\
\hline 11 & .58 & LE11 \\
\hline 25 & .59 & LD11 \\
\hline 19 & .59 & LD5 \\
\hline 1 & .59 & LE1 \\
\hline 8 & .59 & LE8 \\
\hline 24 & .60 & LD10 \\
\hline 7 & .60 & LE7 \\
\hline 28 & .61 & LI2 \\
\hline 31 & .61 & LI5 \\
\hline 3 & .61 & LE3 \\
\hline 32 & .62 & LI6 \\
\hline 14 & .62 & LE14 \\
\hline 10 & .63 & LE10 \\
\hline 36 & .63 & SS3 \\
\hline 33 & .64 & LI7 \\
\hline 9 & .64 & LE9 \\
\hline 13 & .65 & LE13 \\
\hline 6 & .65 & LE6 \\
\hline 2 & .65 & LE2 \\
\hline 29 & .66 & LI3 \\
\hline 27 & .66 & LI1 \\
\hline 16 & .67 & LD2 \\
\hline 26 & .67 & LD12 \\
\hline 21 & .68 & LD7 \\
\hline 30 & .70 & LI4 \\
\hline 23 & .72 & LD9 \\
\hline 20 & .75 & LD6 \\
\hline 15 & .78 & LD1 \\
\hline
\end{tabular}

Table 6 indicated the INFIT and OUTFIT MNSQ value of item fit. Analyses of item fit refer to the value documented in the infit and outfit Mean Square (MNSQ). Observations on the value of the index are required to determine whether the item developed is appropriate (item fit) to measure a latent variable or construct. Based on the Bond and Fox [120], to determine the suitability of the item built, the infit and outfit MNSQ should be in the range of between 0.6 to 1.4. According to Jailani [122], outfit MNSQ should be given more emphasis than Infit MNSQ in determining congruity items that measure constructs. If the result showed value over 1.4 logit means that the item is confusing, meanwhile if the result showed value below 0.6 logit, it means that the item is too easy as expected by the respondents [123]. In addition, the value of infit and outfit ZSTD should be within -2 to +2 [120]. But if the value of infit and outfit MNSQ is accepted, then the ZSTD index can be ignored [123]. The results of this pilot study analysis found that there were six items that are not in the specified 
range and it should be dropped or defined. These items are items LE4, LE12, SS2, SS3, SS4, and LD9. In this study, all of the items listed were refined and retained for the purposes of the study, based on expert's views.

TABLE VI

ITEM FIT

\begin{tabular}{|l|l|l|l|l|l|}
\hline \multirow{2}{*}{$\begin{array}{l}\text { Entry } \\
\text { Number }\end{array}$} & \multicolumn{2}{|c|}{ Infit } & \multicolumn{2}{c|}{ Outfit } & Items \\
\cline { 2 - 5 } & MNSQ & ZSTD & MNSQ & ZSTD & \\
\hline 4 & 2.03 & 3.3 & 1.95 & 3.1 & LE4 \\
\hline 12 & 1.75 & 2.5 & 1.64 & 2.2 & LE12 \\
\hline 35 & 1.54 & 1.9 & 1.51 & 1.9 & SS2 \\
\hline 36 & 1.45 & 1.7 & .63 & .61 & SS3 \\
\hline 37 & 1.47 & 1.7 & 1.45 & 1.7 & SS4 \\
\hline 1 & 1.32 & 1.3 & 1.24 & 1.0 & LE1 \\
\hline 17 & 1.26 & 1.1 & 1.22 & .9 & LD3 \\
\hline 11 & 1.26 & 1.0 & 1.25 & 1.0 & LE11 \\
\hline 7 & 1.21 & .9 & 1.20 & .8 & LE7 \\
\hline 26 & 1.15 & .7 & 1.13 & .6 & LD12 \\
\hline 18 & 1.14 & .6 & 1.10 & .5 & LD4 \\
\hline 10 & 1.12 & .5 & 1.13 & .6 & LE10 \\
\hline 19 & 1.05 & .3 & 1.07 & .4 & LD5 \\
\hline 34 & 1.03 & .2 & 1.02 & .2 & SS1 \\
\hline 9 & .99 & .0 & 1.02 & .2 & LE9 \\
\hline 31 & .90 & -.3 & .98 & .0 & LI5 \\
\hline 27 & .96 & -.1 & .98 & .0 & LI1 \\
\hline 3 & .98 & .0 & .91 & -.3 & LE3 \\
\hline 5 & .93 & -.2 & .91 & -.3 & LE5 \\
\hline 2 & .92 & -.2 & .86 & -.5 & LE2 \\
\hline 8 & .92 & -.2 & .92 & -.2 & LE8 \\
\hline 14 & .90 & -.3 & .88 & -.4 & LE14 \\
\hline 25 & .88 & -.4 & .86 & -.5 & LD11 \\
\hline 20 & .88 & -.4 & .86 & -.5 & LD6 \\
\hline 32 & .78 & -.8 & .85 & -.6 & LI6 \\
\hline 6 & .84 & -.6 & .82 & -.7 & LE6 \\
\hline 16 & .78 & -.9 & .75 & -1.0 & LD2 \\
\hline 30 & .75 & -1.0 & .75 & -1.0 & LI4 \\
\hline 24 & .72 & -1.1 & .72 & -1.2 & LD10 \\
\hline 21 & .70 & -1.3 & .71 & -1.2 & LD7 \\
\hline 22 & .68 & -1.3 & .71 & -1.2 & LD8 \\
\hline 33 & .68 & -1.4 & .68 & -1.3 & LI7 \\
\hline 29 & .65 & -1.5 & .68 & -1.3 & LI3 \\
\hline 15 & .68 & -1.4 & .67 & -1.4 & LD1 \\
\hline 13 & .65 & -1.5 & .64 & -1.6 & LE13 \\
\hline 28 & .61 & -1.7 & .63 & -1.6 & LI2 \\
\hline 23 & -2.7 & .48 & -2.5 & LD9 \\
\hline
\end{tabular}

Table 7 indicated the MNSQ outfit value of standardised residual correlation. Standardised residual correlation measurement value is to determine whether there are items that overlap. High residual correlations for the two items showed the item is not independent, either because the item has the same characteristics among each other or for both incorporate several other dimensions that are shared. According to Linacre [121], if the correlation value above 0.7 , it showed a high correlation value where only one item is to be maintained while the other items have been dropped or defined. The analysis showed that six items were overlapping based on the correlation established. Items that should be dropped or defined are LE3, SS2, LE1, SS4, LE4, and SS2. In this study, all of the items listed were refined and retained for the study since they were still needed in the instrument, based on expert's views.
TABLE VII

STANDARDIZED RESIDUAL CORRELATIONS

\begin{tabular}{|l|l|l|l|l|l|l|}
\hline $\begin{array}{l}\text { Correlat } \\
\text { ion }\end{array}$ & $\begin{array}{l}\text { Entry } \\
\text { Number }\end{array}$ & $\begin{array}{l}\text { MNSQ } \\
\text { Outfit }\end{array}$ & Result & $\begin{array}{l}\text { Entry } \\
\text { Number }\end{array}$ & $\begin{array}{l}\text { MNSQ } \\
\text { Outfit }\end{array}$ & Result \\
\hline .81 & 2 & .86 & Retained & 3 & .91 & Refined \\
\hline .81 & 34 & 1.02 & Retained & 35 & 1.51 & Refined \\
\hline .81 & 1 & 1.24 & Refined & 2 & .86 & Retained \\
\hline .77 & 34 & 1.02 & Retained & 37 & 1.45 & Refined \\
\hline .73 & 4 & 1.95 & Refined & 5 & .91 & Retained \\
\hline .72 & 35 & 1.51 & Refined & 37 & 1.45 & Retained \\
\hline .66 & 1 & 1.24 & Retained & 3 & .91 & Retained \\
\hline .65 & 7 & 1.20 & Retained & 8 & .92 & Retained \\
\hline .64 & 15 & .67 & Retained & 16 & .75 & Retained \\
\hline .62 & 5 & .91 & Retained & 6 & .82 & Retained \\
\hline
\end{tabular}

\section{Variable Map}

Fig. 1 showed the Person Item Distribution Map (PIDM). PIDM showed the items or respondents map that indicates whether the instrument is produced in accordance with the respondent's ability to agree. According to Rashid et. al [124], PIDM is concerned on how the persons' ability on the latent trait responds to item difficulty. Person distribution which is shown in the left side of Fig. 1 showed that $56.25 \%$ of the respondents portrayed a high agreement to the construct and $43.25 \%$ of the respondents expressed low. The distributions of the person indicated that it is able to be easily agreed upon by the respondent. Meanwhile, item distribution shown on the right side showed the level of item difficulty. Mean $n_{\text {item }}$ acts as the threshold and is set to be zero on the logit scale. The item at the higher location than Mean $_{\text {item }}$ showed the higher level of difficulty compared to the item at the lower location. Item LE2 and LE3 are the easiest items meanwhile, item LE11 and LI14 are the most difficult item in this study. The distributions of the items indicate the level of difficulty of the item is nearly balanced.



Fig. 1 Distribution of difficulty level

\section{CONCLUSIONS}

The finding showed that POCLQ instruments had high reliability with five categories of difficulties items. So, it can be concluded that POCLQ instrument is reliable and strongly accepted. The findings on items polarity also indicated that the instrument could measure any item to be measured, and it move parallel with other items that measure the construct. However, based on the analysis of item fit, six items were 
found to be out of 0.6-1.4 range. Moreover, from the analysis on standard residual correlations, five items were found to be overlapping. However, all the items that needed to be dropped based on the analysis of result had been refined and retained for the purpose of the study and based on expert's view.

In determining the quality of an instrument being developed, the best method used by most researchers is analysing items [107]. In this study, Rasch measurement model was used to analyse each item in Perception of Online Collaborative Learning Questionnaire (POCLQ). Application of Rasch model in the instrument can determine the construct validity of items and gave a clear definition of constructs that can be measured are consistent with theoretical expectations. It is hoped that this study will give emphasis to other researchers about the importance of analysing items to ensure the quality of an instrument developed.

\section{ACKNOWLEDGMENT}

Sharifah Nadiyah Razali would like to acknowledge the financial support of Universiti Teknikal Malaysia Melaka (UTeM) and the Ministry of Higher Education of Malaysia for her Ph.D. study.

\section{REFERENCES}

[1] M. B. Othman, "Tahap kompetensi pelajar melaksanakan kerja amali berpandukan domain psikomotor simpson," 2012.

[2] G. Albano, "A knowledge-skill-competencies e-learning model in mathematics," Conoc. destrezas y competencias Un Model. para aprender matemáticas en un entorno virtual, vol. 9, no. 1, pp. 306319, 2012.

[3] R. Ismail, I. Yussof, and L. W. Sieng, "Employers' perceptions on graduates in Malaysian services sector," International Business Management, vol. 5, no. 3. pp. 184-193, 2011.

[4] M. Abdullah-Al-Mamun, "The Soft Skills Education for the Vocational Graduate: Value as Work Readiness Skills," Br. J. Educ. Soc. Behav. Sci., vol. 2, no. 4, pp. 326-338, 2012.

[5] L. S. Vygotsky, Mind in Society. Cambridge (Massachusetts): Harvard University Press, 1978.

[6] S. Ashton-Hay, "Constructivism and powerful learning environments: create your own!," in 9th International English Language Teaching Convention, 2006.

[7] C. Zhu, "Student Satisfaction, Performance, and Knowledge Construction in Online," Educ. Technol. Soc., vol. 15, no. 1, pp. 127136, 2012.

[8] H.-J. Lee and C. Lim, "Peer Evaluation in Blended Team ProjectBased Learning; What Do Students Find Important?," Educ. Technol. Soc., vol. 15, no. 4, pp. 214-224, 2012.

[9] M. K. Kabilan, W. F. W. Adlina, and M. A. Embi, "Online Collaboration of English Language Teachers for Meaningful Professional Development Experiences.," English Teach. Pract. Crit., vol. 10, no. 4, pp. 94-115, 2011.

[10] A. S. Nurbiha, "Cognitive Engagement in Computer Supported Collaborative Learning Environment," Universiti Teknologi Malaysia, 2012.

[11] M. Nyikos and R. Hashimoto, "Constructivist theory applied to collaborative learning in teacher education: In search of ZPD," Mod. Lang. J., vol. 81, no. 4, pp. 506-517, 1997.

[12] I. Alzahrani and J. Woollard, "The Role of the Constructivist Learning Theory and Collaborative Learning Environment on Wiki Classroom, and the Relationship between Them," in Online Submission, 2013.

[13] R. Chiong and J. Jovanovic, "Collaborative Learning in Online Study Groups: An Evolutionary Game Theory Perspective," J. Inf. Technol. Educ. ..., vol. 11, pp. 81-101, 2012.

[14] L. Freeman and L. Greenacre, "An examination of socially destructive behaviors in group work," J. Mark. Educ., vol. 33, no. 1, pp. 5-17, 2011.
[15] A. Young, "Structuring asynchronous discussions to incorporate learning principles in an online class: One professor's course analysis," MERLOT J. Online Learn. Teach., vol. 4, no. 2, pp. 217225, 2008.

[16] R. Santhanam, S. Sharath, and W. Jane, "Using self-regulatory learning to enhance e-learning-based information technology training.," Inf. Syst. Res., vol. 19, no. 1, pp. 26-47, 2008.

[17] H.-J. So and T. A. Brush., "Student perceptions of collaborative learning, social presence and satisfaction in a blended learning environment: Relationships and critical factors.," Comput. Educ., vol. 51, no. 1, pp. 318-336, 2008.

[18] J.-H. Wu, R. D. Tennyson, and T.-L. Hsia, "A study of student satisfaction in a blended e-learning system environment," Comput. Educ., vol. 5, no. 1, pp. 155-164, 2010.

[19] Q. Wang, "Using online shared workspaces to support group collaborative learning," Comput. Educ., vol. 55, no. 3, pp. 12701276, Nov. 2010.

[20] Z. Zhang and Z. Han, "A Phenomenographic Study into Conceptions of Social Relations in Online Collaborative Learning - Case Study of China Higher Education Learners," in IEEE International Conference on Computer Science and Software Engineering (ICCSSE), 2008, pp. 146-149.

[21] A. Zhang, "Peer Assessment of Soft Skills and Hard Skills," J. Inf. Technol. Educ. Res., vol. 11, pp. 155-168, 2012.

[22] A. Burke, "Group Work: How to Use Groups Effectively," J. Eff. Teach., vol. 11, no. 2, pp. 87-95, 2011.

[23] N. Capdeferro and M. Romero, "Are online learners frustrated with collaborative learning experiences?," Int. Rev. Res. Open Distance Learn., vol. 13, no. 2, pp. 26-44, 2012.

[24] K. Swan, J. Shen, and S. R. Hiltz, "Assessment and Collaboration in Online Learning," Jaln, vol. 10, pp. 45-62, 2006.

[25] J. Trimbur, The Call to Write, Sixth Edit. Wadworth Cengage Learning, 2013.

[26] T. J. Ellis and W. Hafner, "Building a framework to support projectbased collaborative learning experiences in an asynchronous learning network," Interdiscip. J. E-Learning Learn. Objects, vol. 4, no. 1, pp. 167-190, 2009.

[27] S. Caruana, "Accreditation of Soft Skills in Higher Education using ICT ." pp. 1-13, 2011.

[28] A. D. Greenberg and A. H. Nilssen, "The Role of Education in Building Soft Skills," 2014.

[29] M. W. L. Fong and R. Sims, "e-WIL in Student Education," Interdiscip. J. E-Learning Learn. Objects, vol. 6, 2010.

[30] L. Kearns, "Student Assessment in Online Learning: Challenges and Effective Practices," MERLOT J. Online Learn. Teach., vol. 8, no. 3, pp. 198-208, 2012.

[31] B. D. Arend, "Course Assessment Practices and Student Learning Strategies in Online Courses," J. Asynchronous Learn. Networks, vol. 11, no. February, pp. 3-18, 2006.

[32] J. Gaytan and B. C. McEwen, "Effective Online Instructional and Assessment Strategies," Am. J. Distance Educ., vol. 21, no. 3, pp. 117-132, 2007.

[33] R. Gleadow, B. Macfarlan, and M. Honeydew, "Design for learning - a case study of blended learning in a science unit," F1000Research, vol. $4: 898,2015$.

[34] E. Strømman, "Participant activity and facilitator strategies in an LMS-based discussion forum," Nord. J. Digit. Lit., vol. 10, no. 12015, pp. 43-62, 2015.

[35] H. Afendi, E. Mohamed Amin, and S. Abdul Halim, "Learning Management Systems in Malaysian Higher Education Institutions," 2011.

[36] W. W. M. Ada, "Computer supported collaborative learning and higher order thinking skills: A case study of textile studies," Interdiscip. J. E-Learning Learn. Objects, vol. 5, pp. 145-167, 2009.

[37] C. Filigree, "Instructional Technology and Collaborative Learning Best Practices : Global Report and Recommendations," 2012.

[38] P. Sancho, J. Torrente, E. J. Marchiori, and B. Fernández-Manjón, "Enhancing moodle to support problem based learning. The Nucleo experience," in IEEE Global Engineering Education Conference (EDUCON), 2011, pp. 1177-1182.

[39] E. Ahmad, M. Y. Jailani, and M. A. Aina Aishikin, "Developing soft skill in Advanced Technology Training Centre ( ADTEC ): an analysis of comparison," Elixir Soc. Stud., vol. 39, pp. 4895-4904, 2011.

[40] A. Hennessey and R. A. Dionigi, "Implementing cooperative learning in Australian primary schools: Generalist teachers' perspectives," Issues Educ. Res., vol. 23, no. 1, pp. 52-68, 2013. 
[41] R. M. Gillies and M. Boyle, "Teachers' reflections on cooperative learning: Issues of implementation," Teach. Teach. Educ., vol. 26, no. 4, pp. 933-940, 2010.

[42] K. Swan, J. Shen, S. R. S. Hiltz, and J. Shen, "Assessment and collaboration in online learning," J. Asynchronous Learn. ..., vol. 10, no. 1, pp. 45-62, 2006.

[43] J. E. J. Brindley, L. M. L. Blaschke, and C. Walti, "Creating effective collaborative learning groups in an online environment," Int. Rev. Res. Open Distance Learn., vol. 10, no. 3, pp. 1-18, 2009.

[44] M. a Andresen, "Asynchronous discussion forums: success factors, outcomes, assessments, andlnlimitations," Educ. Technol. Soc., vol. 12, no. 1, pp. 249-257, 2009.

[45] M. N. H. Mohamad Said, M. Forret, and C. Eames, "Online collaborative learning in tertiary ICT education: Constraints and suggestions for improvement," in Proceedings - 2013 International Conference on Informatics and Creative Multimedia, ICICM 2013, 2013, pp. 153-158.

[46] D. Balliet, "E-Research Collaboration and the Free-Rider Problem: Communication Solutions to Social Dillemas in Computer Mediated Research Collaboration," in e-Research Collaboration: Theory, Techniques and Challenges, Springer Berlin Heidelberg, 2010, pp. 277-287.

[47] A.-H. Carlos, B.-L. Miguel L., G.-S. Eduardo, A.-P. Juan I., E.-G. Guillermo, and R.-C. Adolfo, "Enhancing Learning Environments by Integrating External Applications,” Bull. IEEE Tech. Comm. Learn. Technol., vol. 15, no. 1, pp. 21-24, 2013.

[48] H. Coates, R. James, and G. Baldwin, "A critical examination of the effects of learning management systems on university teaching and learning," Tert. Educ. Manag. 11(1)19-36, 2005., vol. 11, no. 1, pp. 19-36, 2005.

[49] R. Queirós, J. P. Leal, and J. Paiva, "Integrating Rich Learning Applications in LMS," State-of-the-Art Futur. Dir. Smart Learn., pp. 381-386, 2015

[50] K. Kuosa, D. Distante, A. Tervakari, L. Cerulo, A. Fernandez, J. Koro, and M. Kailanto, "Interactive Visualization Tools to Improve Learning and Teaching in Online Learning Environments," Int. J. Distance Educ. Technol., vol. 14, no. 1, 2016.

[51] A. I. Ilyas, "Interactive Tutoring in Blended Studies : Hindrances and Solutions," Int. J. Appl. Linguist. English Lit., vol. 5, no. 1, pp. 2-3, 2016.

[52] C. Beer, K. Clark, and D. Jones, "Indicators of engagement," Proc. ASCILITE 2010, pp. 75-86, 2010.

[53] S. Witte, J. Graham, E. Grysko, S. Bistrican, and A. Piotrowski, "Every Voice Counts: Partnering Literature and LiveScribe," 2013.

[54] C.-T. Tsai, H.-T. Lin, M.-H. Hung, C.-F. Lin, and S.-M. Yuan, "Exchanging Course Content Mechanism for Moodle LMS," in 2010 International Conference on Cyber-Enabled Distributed Computing and Knowledge Discovery, 2010, pp. 464-467.

[55] F. J. Díaz, M. A. Schiavoni, M. A. Osorio, A. P. Amadeo, and M. E. Charnelli, "Integrating a learning management system with a student assignments digital repository: a case study," Int. J. Contin. Eng. Educ. Life Long Learn., vol. 25, no. 2, pp. 138-150, 2015.

[56] A. H. A. Abdallah, "E-Learning Management System from The Perspective of The Social Requirements," Zarqa University, 2016.

[57] capterra.com, "Top LMS Software," 2012. [Online]. Available: http://www.capterra.com/learning-management-systemsoftware/\#infographic.

[58] S. Kim, J. Youn, and Y. Kim, "Design of Expanded Assessment Management System for Open-Source Moodle LMS Module," in 3rd International Conference on e-Education, e-Business, e-Management and e-Learning (IPEDR), 2012, vol. 27, pp. 43-47.

[59] H. Fung and A. Yuen, "Factors Affecting Students' and Teachers' Use of LMS - Towards a Holistic Framework," in Hybrid Learning, vol. 74411, 2012, pp. 306-316.

[60] A. Norazlina, "Kesan Penyesuaian Pembelajaran Berdasarkan Gaya Pembelajaran Terhadap Pembentukan Pengetahuan Pelajar," Universiti Teknologi Malaysia, 2014.

[61] B. M. A. D. Mastura, "A Framework on Collaborative Learning Activities to Actively Engage Students in Learning Management System," Universiti Teknikal Malaysia Melaka, 2016.

[62] C. Kivunja, "Exploring the Pedagogical Meaning and Implications of the 4Cs 'Super Skills' for the 21 st Century through Bruner's 5E Lenses of Knowledge Construction to Improve Pedagogies of the New Learning Paradigm," Creat. Educ., vol. 6, no. February, pp. 224-239, 2015.

[63] A. Al-Ansari, F. Al-Harbi, W. AbdelAziz, M. AbdelSalam, M. M. El Tantawi, and I. ElRefae, "Factors affecting student participation in extra-curricular activities: A comparison between two Middle Eastern dental schools," Saudi Dent. J., vol. 28, no. 1, pp. 36-43, 2016.

[64] S. Kumar, A. K. Gankotiya, and K. Dutta, "A comparative study of moodle with other e-learning systems," in 2011 IEEE 3rd International Conference on Electronics Computer Technology, 2011, pp. 414-418.

[65] D.-Z. Marijana, B. L. Aleksandra, and R. M. Aleksandar, "Fostering engineering e-learning courses with social network services," in 19th IEEE Telecommunications Forum (TELFOR), 2011, pp. 122-125.

[66] H. N. Nguyen, H. Kim, Y. Jo, and K. Dieter, "Sharing Cognition LMS: An Alternative Teaching and Learning Environment for Enhancing Collaborative Performance," Educ. Technol. Int., vol. 16, no. 1, pp. 1-30, 2015.

[67] M. Said, M. Forret, and C. Eames, "Analysis of Contradictions in Online Collaborative Learning using Activity Theory as Analytical Framework," J. Teknol., vol. 2, pp. 57-63, 2014.

[68] S. A. Ishan and C. Y. Tham, "Implementation of Facebook Study Groups as Supplements for Learning Management Systems ( LMS ) in Adult ODL Environments," Asian Assoc. Open Univ. Journal, vol. 7, no. 1, pp. 1-11, 2011.

[69] R. Hern'ndez, H. R. Amado-Salvatierra, C. Guetl, and M. Smadi, "Facebook for CSCL, Latin-American Experience for Professors," in 2012 IEEE 12th International Conference on Advanced Learning Technologies, 2012, pp. 327-328.

[70] J. Martins, R. Gonçalves, V. Santos, and J. Pereira, "Network Based Model For E-Learning 2.0," Procedia - Soc. Behav. Sci., vol. 47, no. 0 , pp. 1242-1248, 2012.

[71] Z. Du, X. Fu, C. Zhao, Q. Liu, and T. Liu, "Interactive and Collaborative E-Learning Platform with Integrated Social Software and Learning Management System," in International Conference on Information Technology and Software Engineering, 2013, vol. 212, pp. 11-19.

[72] F. Ataie, A. Shah, and M. N. Mior Nazir, "Innovative web 2.0 based collaborative learning and study circle model," in The 5th International Conference on Information and Communication Technology for The Muslim World (ICT4M), 2014, pp. 1-6.

[73] Schroeder, A., S. Minocha, and C. Schneider, "Social Software in Higher Education: The Diversity of Applications and Their Contributions to Students' Learning Experiences," Commun. Assoc. Inf. Syst., vol. 25, no. 1, pp. 547-564, 2010.

[74] A. J. Y. Zaidieh, "The Use of Social Networking in Education: Challenges and Opportunities," World Comput. Sci. Inf. Technol. J., vol. 2, no. 1, pp. 18-21, 2012.

[75] Y. Chen, "Learning styles and adopting Facebook technology," in Technology Management in the Energy Smart World (PICMET), 2011, pp. 1-9.

[76] R. Ajjan, H., Hartshorne, Investigating faculty decisions to adopt Web 2.0 technologies: theory and empirical tests. 2008.

[77] N. Selwyn, "“ Screw Blackboard ... do it on Facebook !': an investigation of students ' educational use of Facebook," in Poke 1.0 - Facebook social research symposium', 2007, no. November, pp. 123.

[78] R. Mason, "Learning technologies for adult continuing education," Stud. Contin. Educ., vol. 28, no. 2, pp. 121-133, Jul. 2006.

[79] P. Ventura and E. Martin-Monje, "Learning specialised vocabulary through Facebook in a massive open online course," in New perspectives on teaching and working with languages in the digital era, A. Parej-Lora, C. Calle-Martinez, and P. Rodriguez-Arancon, Eds. Research-publishing.net, 2016, pp. 117-128.

[80] W. Rifkin, N. Longnecker, J. Leach, L. Davis, and L. Ortia, "Motivate students by having them publish in new media: An invitation to science lecturers to share and tes," in Motivating Science Undergraduates: Ideas and Interventions, UniServe Science Proceedings, 2009.

[81] S. Wheeler, P. Yeomans, and D. Wheeler, "The good, the bad and the wiki: Evaluating student-generated content for collaborative learning," Br. J. Educ. Technol., vol. 39, no. 6, pp. 987-995, 2008.

[82] K. Zourou, "On the attractiveness of social media for language learning: a look at the state of the art," OpenEdition, vol. 15, no. 1, 2012.

[83] B. V. N. Smith, "Use of online educational social networking in a school environment," North Carolina State University, Raleigh, NC, 2009.

[84] M. Barbour and C. Plough, "Social networking in cybershcooling: Helping to make online learning less isolating.," TechTrends, vol. 53, no. 4, pp. 56-60, 2009. 
[85] M. H. Zakaria, "E-Learning 2 . 0 Experiences Within Higher Education : Theorising Students ' and Teachers' Experiences in Web 2.0 learning," Quensland University of Technology, 2013.

[86] K. Silius, T. Miilumäki, J. Huhtamäki, T. Tebest, J. Meriläinen, and S. Pohjolainen, "Students' Motivations for Social Media Enhanced Studying and Learning," Knowl. Manag. E-Learning An Int. J., vol. 2, pp. 51-67, 2010.

[87] P. A. Kirschner and A. C. Karpinski, "Facebook® and academic performance," Comput. Human Behav., vol. 26, no. 6, pp. 1237-1245, 2010.

[88] J. Cassidy, "Me media," New Yorker 82, vol. no 13:50-9, 2006

[89] M. Kalpidou, D. Costin, and J. Morris, "The Relationship Between Facebook and the Well-Being of Undergraduate College Students," Cyberpsychology, Behav. Soc. Netw., vol. 14, no. 4, pp. 183-189, 2011.

[90] Gemmill and Petterson, "Technology use among college students: Implications for student affairs professionals," NASPA J., vol. 43, no. 2, pp. 280-300, 2008.

[91] P. A. Kirschner and A. C. Karpinski, "Facebook and Academic Performance 1," Comput. Human Behav., vol. 26, no. 6, pp. 1237$1245,2010$.

[92] J. Pasek, E. More, and E. Hargittai, "The FG study," Peer-Reviewed J. Internet, vol. 14, no. 5, pp. 1-14, 2009.

[93] Q. Wang, W. Chen, and Y. Liang, "The Effects of Social Media on College Students," MBA Student Scholarsh., p. Paper 5, 2011.

[94] N. A. Buzzetto-more, "Social Networking in Undergraduate Education," Interdiscip. J. Information, Knowledge, Manag., vol. 7, pp. 63-90, 2012.

[95] M. Al-Zoube, "E-Learning on the Cloud," Int. Arab J. e-technology, vol. 1, no. 2, pp. 58-64, 2009.

[96] J. McCarthy, "Utilising Facebook: immersing Generation-Y students into first year university," J. Educ. Res. Gr. Adelaide, vol. 1, no. 2, pp. 39-50, 2009.

[97] R. Sharifah Nadiyah, S. Faaizah, H. Hanipah, and B. Norasiken, "Online collaborative learning elements to propose an online project based collaborative learning model," J. Teknol., vol. 77, no. 23, pp. 55-60, 2015.

[98] R. Sharifah Nadiyah, S. Faaizah, H. Hanipah, and B. Norasiken, "Factors That Affecting The Effective Online Collaborative Learning Environment," Pattern Anal. Intell. Secur. Internet Things, Adv. Intell. Syst. Comput. 355, pp. 293-302, 2014.

[99] R. Sharifah Nadiyah, S. Faaizah, and P. A. Gede, "A Proposed Model for Online Project Based Collaborative Learning: Expert Review," J. Netw. Innov. Comput., vol. 3, pp. 1-6, 2015.

[100] R. Sharifah Nadiyah and S. Faaizah, "The Development of Online Project Based Collaborative Learning Using ADDIE Model," Procedia - Soc. Behav. Sci., vol. 195, pp. 1803-1812, 2015.

[101] A. B. Jamil, "Model Pembelajaran Informal bagi Guru yang Mengajar Matapelajaran Teknologi Kejuruteraan," Universiti Tun Hussien Onn, 2014

[102] C. L. Kimberlin and A. G. Winterstein, "Validity and reliability of measurement instruments used in research," Am J Heal. Syst Pharm, vol. 65, no. 23, pp. 2276-84, 2008.

[103] J. Creswell, Educational research: Planning, conducting and evaluating quantitative and qualitative research. Upper Saddle River, NJ: Merril, 2005.

[104] R. M. Yasin, F. A. N. Yunus, R. C. Rus, A. Ahmad, and M. B. Rahim, "Validity and Reliability Learning Transfer Item Using Rasch Measurement Model," Procedia - Soc. Behav. Sci., vol. 204, no. 2015 , pp. $212-217,2015$.
[105] D. Gay and Airasian, "The Rating Scale Model," in Linden W. J. \& Hambleton R. K.: Handbook of Modern Item Response Theory, Springer-Verlag: New-York, 2003, p. Chapter 4, 67-148.

[106] S. Aiken, "Estimation Of Item Parameters," in Fisher G. H. \& Molenaar I. W.: Rasch Models, Foudations, Recent Developments And Applications, Springer-Verlag: New-York, 2003, p. Chapter 3, 39-52.

[107] N. M. Hanafi, A. A. Rahman, M. I. Mukhtar, J. Ahmad, and S. Warman, "Validity and Reliability of Competency Assessment Implementation ( CAI ) Instrument Using Rasch Model,” Int. J. Soc. Educ. Econ. Manag. Eng., vol. 8, no. 1, pp. 162-167, 2014.

[108] A. Abdul Aziz, Rasch Model Fundamentals: Scale Construct and Measurement Structure. Kuala Lumpur: Integrated Advanced Planning Sdn.Bhd, 2010.

[109] H. Azman, "Instrument Penilaian Pembimbing dalam Pelaksanaan Pembelajaran Berasaskan Kerja (PBK) Pelajar di Industri," Universiti Tun Hussien Onn, 2012.

[110] M. N. A. Ghaffar, Penyelidikan Pendidikan. Skudai: Penerbit Universiti Teknologi Malaysia., 1999.

[111] A. S. M. Lau, "Hospital-based nurses' perceptions of the adoption of Web 2.0 tools for knowledge sharing, learning, social interaction and the production of collective intelligence.," J. Med. Internet Res., vol. 13, no. 4, p. e92, Jan. 2011.

[112] H. M. Selim, "Critical success factors for e-learning acceptance: ConWrmatory factor models," Comput. Educ., vol. 49, pp. 396-413, 2007.

[113] C. Lorenzo-Romero, M.-C. Alarcón-del-Amo, and E. Constantinides, "Determinants of Use of Social Media Tools in Retailing Sector," $J$ Theor. Appl. Electron. Commer. Res., vol. 9, no. 1, pp. 9-10, 2014.

[114] M. G. Moore, "Three types of interaction.," Am. J. Distance Educ., vol. 3, no. 2, pp. 1-6, 1989.

[115] H. Ali, "A comparison of cooperative learning and traditional lecture methods in the project management department of a tertiary level institution in Trinidad and Tobago," Caribb. Teach. Sch., vol. 1, no. 1, pp. 49-64, 2011.

[116] R. Chomeya, "Quality of Psychology Test Between Likert Scale 5 and 6 Points," J. Soc. Sci., vol. 6, no. 3, pp. 399-403, 2010.

[117] M. Denscombe, The Good Research Guide. Open University Press: McGraw-Hill, 2010.

[118] P. Ruengtam, "Learning Efficiency in Theoretical Subjects of Interior Architecture by Cooperative/Collaborative Learning Technique," in Procedia - Social and Behavioral Sciences, 2012, vol. 68, pp. 281-294.

[119] W. G. Zikmund and B. J. Babin, Essentials of Marketing Research, 4th editio. Australia: South-Western, 2010.

[120] T. G. Bond and C. M. Fox, Applying The Rasch Model: Fundamental Measurement in the Human Sciences, 2nd Editio. Lawrence Erlbaum Associates, Publisers. Mahwah, New Jersey. London., 2007.

[121] J. M. Linacre, Winsteps ${ }^{\circledR}$ Rasch Measurement Computer Program User's Guide. Beaverton, Oregon : Winsteps.com, 2011.

[122] K. M. Jailani, Manual Pengenalan Pengukuran Rasch \& Winstep. Pengukuran dan Penilaian dalam Pendidikan. Fakulti Pendidikan Universiti Kebangsaan Malaysia, 2011.

[123] J. M. Linacre, A user's guide to WINDTEPS Rasch-model computer programs. Chicago, Illinois: MESA Press., 2007.

[124] R. a Rashid, R. Abdullah, Ha. A. Ghulman, and M. S. Masodi, "Application of Rasch-based ESPEGS Model in Measuring Generic Skills of Engineering Students: A New Paradigm," Eng. Educ., vol. 5, no. 8, pp. 591-602, 2008. 